\title{
Article \\ The Effect of Ethanol Treatment on the Quality of a New Table Grape Cultivar It 681-30 Stored at Low Temperature and after a 7-Day Shelf-Life Period at $20^{\circ} \mathrm{C}$ : A Molecular Approach
}

\author{
Irene Romero ${ }^{1}{ }^{\circledR}$, Maria Vazquez-Hernandez ${ }^{1}$, Manuel Tornel ${ }^{2}$, M. Isabel Escribano ${ }^{1}$, Carmen Merodio ${ }^{1}$ and \\ M. Teresa Sanchez-Ballesta ${ }^{1, *(\mathbb{D})}$ \\ 1 Department of Characterization, Quality and Safety, Institute of Food Science, Technology and Nutrition, \\ Spanish National Research Council (ICTAN-CSIC), José Antonio Novais 10, E-28040 Madrid, Spain; \\ irene.romero@ictan.csic.es (I.R.); mavahe86@gmail.com (M.V.-H.); escribano@ictan.csic.es (M.I.E.); \\ merodio@ictan.csic.es (C.M.) \\ 2 Instituto Murciano de Investigación y Desarrollo Agrario y Medioambiental (IMIDA), Mayor, s/n, La Alberca, \\ E-30150 Murcia, Spain; manuel.tornel@carm.es \\ * Correspondence: mballesta@ictan.csic.es
}

Citation: Romero, I.;

Vazquez-Hernandez, M.; Tornel, M.; Escribano, M.I.; Merodio, C.;

Sanchez-Ballesta, M.T. The Effect of Ethanol Treatment on the Quality of a New Table Grape Cultivar It 681-30 Stored at Low Temperature and after a 7-Day Shelf-Life Period at $20^{\circ} \mathrm{C}$ : A Molecular Approach. Int. J. Mol. Sci. 2021, 22, 8138. https://doi.org/ $10.3390 /$ ijms 22158138

Academic Editor: Fabrizio Grassi

Received: 7 July 2021

Accepted: 26 July 2021

Published: 29 July 2021

Publisher's Note: MDPI stays neutral with regard to jurisdictional claims in published maps and institutional affiliations.

Copyright: (c) 2021 by the authors. Licensee MDPI, Basel, Switzerland. This article is an open access article distributed under the terms and conditions of the Creative Commons Attribution (CC BY) license (https:// creativecommons.org/licenses/by/ $4.0 /)$.

\begin{abstract}
Despite the fact that many studies have examined the effectiveness of different gaseous postharvest treatments applied at low temperature to maintain table grape quality, the use of ethanol vapor has hardly been investigated. Thus, this work has studied the effectiveness of ethanol vaporgenerating sachets in the maintenance of It 681-30 table grape quality, a new cultivar, during storage at low temperature and after the shelf-life period at $20^{\circ} \mathrm{C}$. To this end, various quality assessments have been carried out and the effect of the ethanol treatment on the expression of different genes (phenylpropanoids, transcription factors, PRs, and aquaporins) was determined. The results indicated that the application of ethanol vapor reduced the total decay incidence, weight loss, and the rachis browning index in It $681-30$ grapes stored at $0{ }^{\circ} \mathrm{C}$ and after the shelf-life period at $20^{\circ} \mathrm{C}$, as compared to non-treated samples. Moreover, the modulation of STS7 and the different PR genes analyzed seems to play a part in the molecular mechanisms activated to cope with fungal attacks during the postharvest of It 681-30 grapes, and particularly during the shelf-life period at $20^{\circ} \mathrm{C}$. Furthermore, the expression of aquaporin transcripts was activated in samples showing higher weight loss. Although further work is needed to elucidate the role of ethanol in table grape quality, the results obtained in this work provide new insight into the transcriptional regulation triggered by ethanol treatment.
\end{abstract}

Keywords: table grapes; ethanol; low temperature; fruit quality; gene expression

\section{Introduction}

Table grape is a non-climacteric fruit, subject to water loss and decay during postharvest handling. The storage of table grapes at low temperature (around $0{ }^{\circ} \mathrm{C}$ ), with high relative humidity, is one of the most widely used technologies for maintaining their postharvest quality. However, this is normally not sufficient to avoid senescence of the rachis, abscission of berries, or a fungal attack, mainly caused by Botrytis cinerea, all of which compromise bunch quality (reviewed by [1]). Thus, different postharvest treatments have been applied alongside low-temperature storage to maintain table grape quality, the most used being the modification of the storage atmosphere by increasing the $\mathrm{O}_{2}$ or $\mathrm{CO}_{2}$ concentration [2-8]. Among these treatments, the use of ethanol vapor has been less studied so far. Ethanol is considered to be a "generally recognized as safe" (GRAS) compound [9], and as such, it can be used in the food industry. It has been found that the application of ethanol effectively reduces fungal attack and delays senescence in fruit and vegetables [9-14]. The response of fruit to ethanol depends on different factors, such as the species, cultivar, and maturity, together with the dose and duration of exposure [10]. In the particular case of 
table grapes, it is known that ethanol applied as vapor or in solution limits Botrytis development over the postharvest period, maintaining the organoleptic quality of berries [15-17]. However, while the use of ethanol vapor-generating sachets, such as Antimold ${ }^{\circledR}$, controlled fungal growth [18] and increased the anthocyanin content and antioxidant capacity during storage, it also adversely affected the rachis, inducing browning in Red Globe bunches [19]. It is important to highlight that, to date, most published research reported on the effectiveness of gaseous treatments in table grapes refers to increasing the concentration of $\mathrm{O}_{2}$ or $\mathrm{CO}_{2}$ in the storage atmosphere [1]. Likewise, most studies related to the application of ethanol in table grapes have addressed the effect on bunch quality, but there is still a dearth of knowledge about the mechanisms involved in the effectiveness of this treatment. Consequently, in order to form the basis of knowledge about the effectiveness of ethanol treatments, an in-depth study needs to be conducted of the molecular mechanisms related to their effectiveness, which are currently unknown.

The activation of phenylpropanoid metabolism plays a role in the response of plants to abiotic stress, as well as in the defense against pathogens $[20,21]$. In the case of table grapes, the expression of phenylpropanoid pathway genes has been studied in response to different postharvest treatments. By way of example, applying $5 \mathrm{kPa} \mathrm{O}_{2}$ and $15 \mathrm{kPa}$ $\mathrm{CO}_{2}$ for 6 weeks at $0{ }^{\circ} \mathrm{C}$ activated the expression of $13 P A L$ and 6 STS transcripts in Superior Seedless grapes [8]. Furthermore, short-term treatment with high levels of $\mathrm{CO}_{2}$ activated the accumulation of $\mathrm{CHS}$ transcripts in Autumn Royal table grapes [22] and white Dominga table grapes. Additionally, there was an increase in the accumulation of stilbene compounds in $\mathrm{CO}_{2}$-treated samples, which seems to be modulated by VviSTS6, VviSTS7, and VviSTS46 [23].

Previous research has reported that pathogenesis-related proteins (PRs) seem to have a protective role in table grapes during postharvest. Applying a postharvest treatment with $\mathrm{SO}_{2}$ or $\mathrm{O}_{3}$ delayed fungal growth in Red Globe grapes and increased the accumulation of chitinase and $\beta-1,3$-glucanase transcripts [24]. Likewise, recombinant class I chitinase and $\beta$-1,3-glucanase from table grapes showed in vitro cryoprotective and antifungal activities [25,26]. Moreover, Crimson Seedless lines expressing cisgenic thaumatin-like proteins [27] or chitinase and $\beta$-1,3-glucanase proteins [28] displayed resistance to powdery or downy mildew, respectively.

On the other hand, it is known that in plants, water transport across the membranes is facilitated by the water channel proteins called aquaporins [29]. In addition to water, these proteins facilitate the transport of small neutral solutes and gases [29]. The expression of aquaporin genes decreased in response to water stress in grapes [30] and to low temperature in Arabidopsis [31]. Furthermore, the heterologous expression of PIP1;1 from banana in Arabidopsis confers tolerance to water and salt stress by reducing membrane damage, improving ion distribution and maintaining the osmotic balance [32]. Considering that there is limited information about the role of aquaporins in table grapes during postharvest, its analysis could be helpful to study the effectiveness of postharvest treatments in table grape water status.

In recent years, researchers and companies have focused on breeding new table grape cultivars, resulting in increased growth and profitability for retailers and growers around the world. Hence, it is imperative that these advances are accompanied by the study of the postharvest behavior of these new cultivars. The cultivar It $681-30$ is the result of crossbreeding $(($ Dominga $\times$ Moscatuel $) \times$ Crimson), obtained in a table grape breeding program developed in the region of Murcia (Spain) by the Table Grape Research and Technology Society, ITUM, in collaboration with the Murcia Institute for Agricultural and Food Research and Development (IMIDA). It 681-30 is a late-harvesting cultivar, with a harvest period from mid-September to the end of November. It 681-30 berries are seedless, elliptical in shape, and with a size that varies naturally between 17 and $19 \mathrm{~mm}$, while after treatment with gibberellic acid and girdling, it reaches $22-24 \mathrm{~mm}$. The pulp is juicy, the acidity taste is neutral, and it has a crunchy texture. However, the mechanisms modulated by applying postharvest treatments such as ethanol are, so far, 
unknown for this new cultivar. Thus, this study aimed to explore, on the one hand, the postharvest behavior of the new It 681-30 cultivar during storage at low temperature, and on the other hand, the molecular mechanisms linked to the effectiveness of ethanol vapor-generating sachets in the maintenance of the It 681-30 table grapes quality. To this end, different quality parameters have been analyzed in ethanol-treated and nontreated It $681-30$ table grapes stored at $0{ }^{\circ} \mathrm{C}$ for up to 49 days and after a 7-day shelf-life period at $20^{\circ} \mathrm{C}$. Moreover, the expression of genes that encoded PRs (Vcchit1b, Vcchns1, VviTL, and VviOsmo1), enzymes (VviPAL, VviCHS, and VviSTS7), and transcription factors (VviMYB13, VviMYB14, and VviMYB137) related to phenylpropanoid biosynthesis and aquaporins (VviPIP1.2, VviPIP1.3, VviPIP2.1, and VviPIP2.2) were studied, for the first time, in ethanol-treated and non-treated table grapes.

\section{Results and Discussion}

2.1. The Effect of an Ethanol Treatment on Quality of It 681-30 Bunches Stored at Low Temperature and during the Shelf-Life Period at $20^{\circ} \mathrm{C}$

In the present study, the postharvest response of the cultivar It 681-30 in low-temperature storage has been analyzed, as well as how the treatment of ethanol vapor-generating sachets can help improve the quality of these table grapes stored at $0{ }^{\circ} \mathrm{C}$ and after 7 days at $20^{\circ} \mathrm{C}$ (Figure 1). The results indicated that SSC increased slightly both in non-treated and ethanoltreated grapes stored at $0{ }^{\circ} \mathrm{C}$ during the period at $20^{\circ} \mathrm{C}$ (Table 1 ). However, TA and $\mathrm{pH}$ did not vary in any condition assayed. Low-temperature storage increased the weight loss in non-treated and ethanol-treated bunches, with this being significantly higher in those bunches stored in air. Moreover, the shelf-life period increased the weight loss, although the percentage of this loss was lower in the ethanol-treated bunches. The total decay was significantly lower in the ethanol-treated table grapes. Furthermore, although the shelf-life period of 7 days at $20^{\circ} \mathrm{C}$ significantly increased total decay in both ethanol-treated and non-treated It 681-30 samples, the values were significantly lower in those that had been treated (Table 1). Regarding the rachis-browning index, only ethanol-treated bunches stored at $0{ }^{\circ} \mathrm{C}$ showed significantly lower values. The results of this study are in concordance with previous works, where the application of ethanol vapor treatments controlled rot development [16]. These authors also observed that rachis browning was lower in ethanoltreated grapes in comparison to the control fruit but not when $\mathrm{SO}_{2}$-treatment was used. However, Lurie et al. [17] observed that rachis desiccation was similar in control, ethanoltreated, and $\mathrm{SO}_{2}$-treated Thompson Seedless table grapes. The effect of ethanol on rachis browning seems to be cultivar-dependent. Thus, Candir et al. [33] indicated that packing Pafi grapes with Antimold ${ }^{\circledR} 60$ sachets resulted in lower weight loss and found no adverse effects as to rachis browning, TA, and SSC after 3 months of storage at $0{ }^{\circ} \mathrm{C}$. 

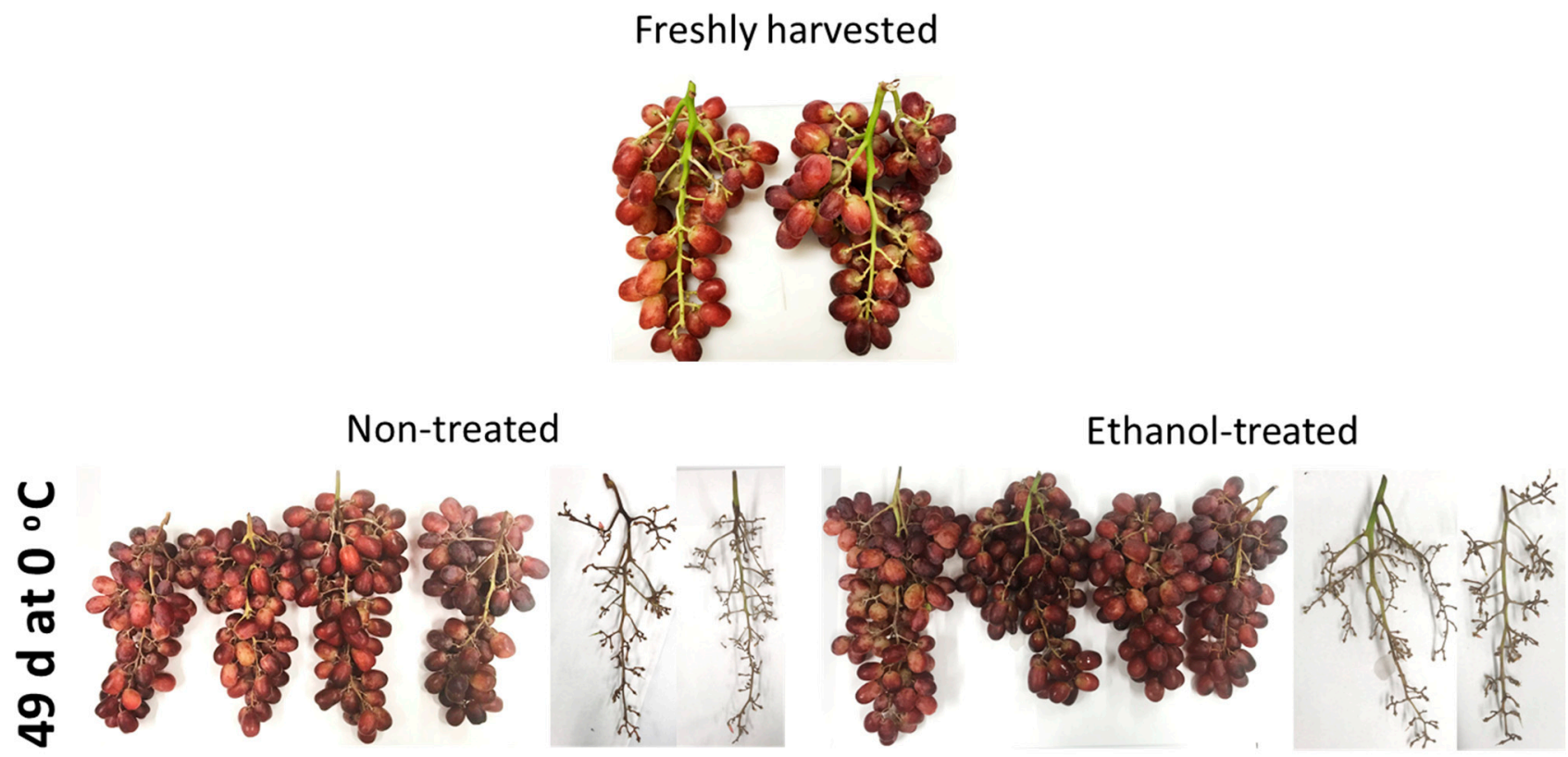

Figure 1. Appearance of It 680-31 grape bunches treated and non-treated with ethanol stored at $0{ }^{\circ} \mathrm{C}$ for up to 49 days.

Table 1. Soluble solids content (SSC), titratable acidity (TA), $\mathrm{pH}$, weight loss, total decay, and rachis browning index of It 681-30 table grapes non-treated and treated with ethanol for 49 days at $0{ }^{\circ} \mathrm{C}$ and after the shelf-life period $(49 \mathrm{~d}+7 \mathrm{~d}$ at $\left.20^{\circ} \mathrm{C}\right)$.

\begin{tabular}{|c|c|c|c|c|c|}
\hline & \multirow[b]{2}{*}{ Freshly-Harvested } & \multicolumn{2}{|r|}{ Air } & \multicolumn{2}{|c|}{ Ethanol } \\
\hline & & $49 \mathrm{~d}{ }^{\circ} \mathrm{C}$ & $49 \mathrm{~d}$ Air $+7 \mathrm{~d} 20^{\circ} \mathrm{C}$ & $49 \mathrm{~d} 0^{\circ} \mathrm{C}$ & $49 \mathrm{~d}+7 \mathrm{~d} 20^{\circ} \mathrm{C}$ \\
\hline SSC (\%) & $19.2 \pm 0.2 \mathrm{a}$ & $20.8 \pm 0.1 \mathrm{~b}$ & $21.4 \pm 0.3 \mathrm{~b}$ & $20.8 \pm 0.4 b$ & $20.5 \pm 0.7 b$ \\
\hline TA (\% Tartaric Acid) & $0.37 \pm 0.04 \mathrm{a}$ & $0.41 \pm 0.00 \mathrm{a}$ & $0.40 \pm 0.00 \mathrm{a}$ & $0.41 \pm 0.00 \mathrm{a}$ & $0.40 \pm 0.00 \mathrm{a}$ \\
\hline Maturity Index (SSC/TA) & 51.89 & 50.48 & 53.15 & 50.43 & 51.04 \\
\hline $\mathrm{pH}$ & $3.82 \pm 0.03 \mathrm{a}$ & $3.84 \pm 0.01 \mathrm{a}$ & $3.84 \pm 0.01 \mathrm{a}$ & $3.84 \pm 0.01 \mathrm{a}$ & $3.80 \pm 0.02 \mathrm{a}$ \\
\hline Weight Loss (\%) & - & $4.29 \pm 0.32 b$ & $7.89 \pm 0.01 \mathrm{~d}$ & $3.24 \pm 0.09 \mathrm{a}$ & $6.61 \pm 0.10 c$ \\
\hline Total Decay (\%) & - & $11.8 \pm 0.2 \mathrm{~b}$ & $59.9 \pm 0.6 \mathrm{~d}$ & $4.0 \pm 0.5 \mathrm{a}$ & $32.7 \pm 0.7 c$ \\
\hline Rachis Browning Index & - & $3.50 \pm 0.50 \mathrm{~b}$ & $4.00 \pm 0.00 \mathrm{~b}$ & $2.50 \pm 0.50 \mathrm{a}$ & $3.50 \pm 0.57 b$ \\
\hline
\end{tabular}

Different letters in rows indicate significant differences using the Tukey-b test $(p<0.05)$.

2.2. The Effect of Storage at $0^{\circ} \mathrm{C}$ and the Shelf-Life Period at $20^{\circ} \mathrm{C}$ on the Phenylpropanoid Gene Expression in the Skin of Non-Treated and Ethanol-Treated It 681-30 Table Grapes

Although the beneficial effects of ethanol treatments on table grape quality during postharvest have been reported [17-19,33], to our knowledge, the molecular mechanisms involved in maintaining fruit quality are not yet known. Grapes accumulate a number of secondary metabolites, including flavonoids and stilbenoids, whose synthesis and accumulation are affected by different postharvest conditions $[8,22,23,34]$. The expression of two (VviPAL and $V v i C H S$ ) flavonoid pathway genes as well as one (VviSTS7) and three regulatory (VviMYB14, VviMYB15A, and VviMYB15C) stilbene pathway genes during the storage of non-treated and ethanol-treated It $681-30$ table grapes at $0{ }^{\circ} \mathrm{C}$ and after 7 days at $20{ }^{\circ} \mathrm{C}$ were analyzed.

\subsubsection{Expression of VviPAL, VviCHS, and VviSTS7}

The gene expression of $V v i P A L$ decreased over the course of the storage period at $0{ }^{\circ} \mathrm{C}$ and after 7 days at $20^{\circ} \mathrm{C}$, both in the skin of non-treated and ethanol-treated table grapes (Figure 2). However, a decrease of $\mathrm{VviCHS}$ gene expression was also denoted in non-treated grapes stored at $0{ }^{\circ} \mathrm{C}$. In the case of ethanol-treated samples, the decrease was not noted until day 49 at $0{ }^{\circ} \mathrm{C}$ (Figure 2). At $20^{\circ} \mathrm{C}$, the levels of VviCHS only increased in 
non-treated grapes, reaching values similar to freshly harvested fruit (Figure 2). These gene expression patterns showed a significant positive correlation $(r=0.451, p<0.05)$ (Table 2). While no works have reported the modulation of these genes in ethanol-treated table grapes during postharvest, what has been previously studied is the effect of ethanol on the phenylpropanoid gene expression in Cabernet Sauvignon berries during their development after veraison [35]. These authors observed that spraying grapes at veraison with ethanol at $5 \%$ in water had no stimulating effect on the transcription of CHS, DFR, F3H, and LDOX genes. Furthermore, ethanol treatment was able to inhibit phenolic metabolism, which is critical for tissue browning in lettuce, by repressing the expression of PAL mRNA and inhibiting PAL activity [36].

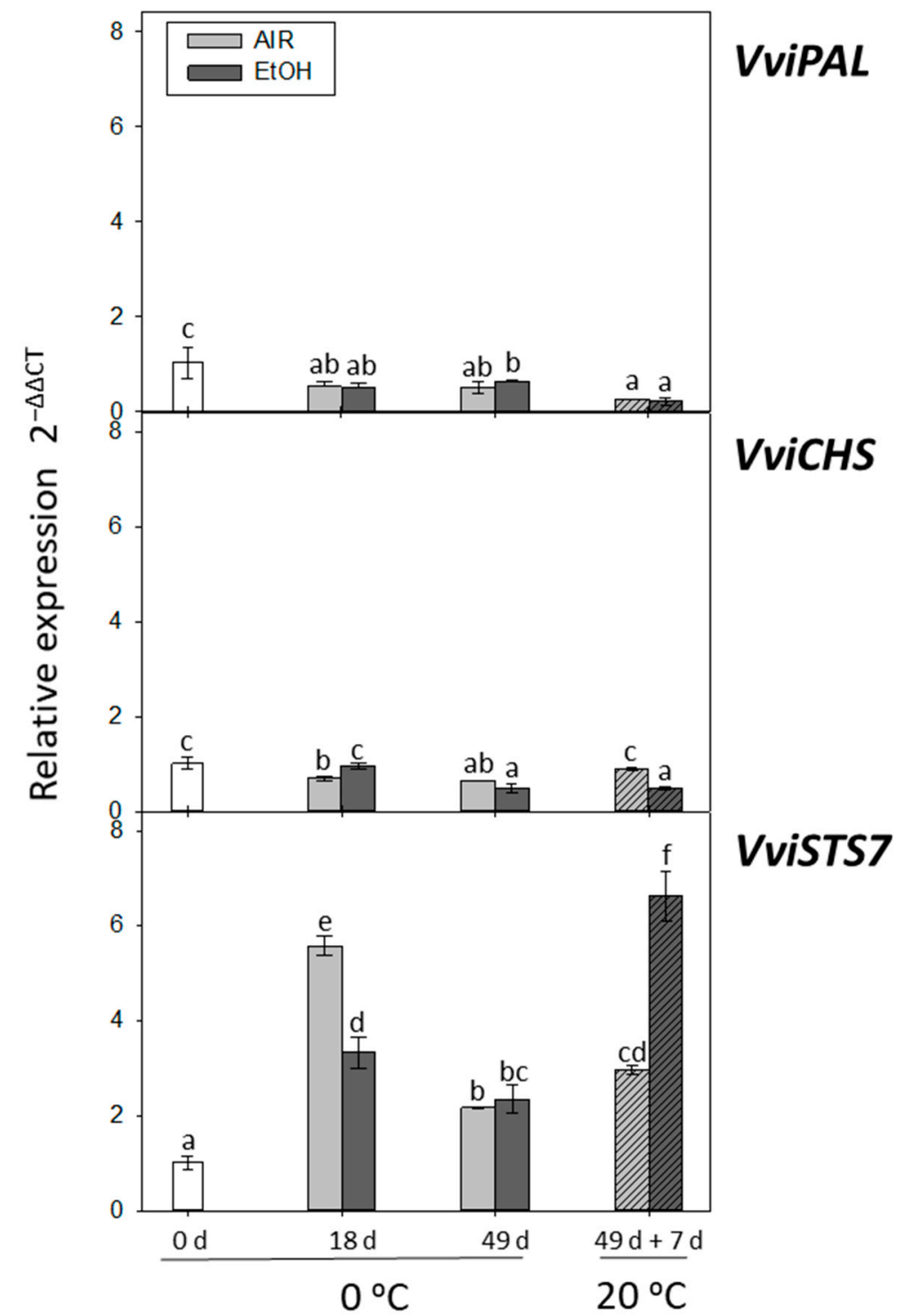

Figure 2. Effect of low temperature and ethanol treatment on VviPAL, VviCHS, and VviSTS7 gene expression in the skin of It 681-30 table grapes stored for 49 days at $0{ }^{\circ} \mathrm{C}$ and after the shelf-life period $\left(49 \mathrm{~d}+7 \mathrm{~d}\right.$ at $\left.20^{\circ} \mathrm{C}\right)$. The transcript levels of each gene were assessed by RT-qPCR and normalized using Actin 1 as a reference gene. The results were calculated relative to a calibrator sample (time 0 ) using the formula $2^{-\Delta \Delta C t}$. Values are the mean $\pm S D, n=6$. Different letters on bars indicate that the means are statistically different using the Tukey-b test $(p<0.05)$.

On the other hand, VviSTS7 gene expression showed a sharp and transient increase at day 18 , both in the skin of ethanol-treated and non-treated It 681-30 grapes, although it was 
higher in non-treated samples (Figure 2). At day 49, transcript accumulation decreased in both samples, decreased to similar levels, which were higher than those recorded for freshly harvested grapes. After the shelf-life period at $20^{\circ} \mathrm{C}$, VviSTS7 gene expression increased in both treated and non-treated table grapes. Yet, the ethanol-treated grapes showed values seven times higher than the freshly harvested ones and twice the levels observed in nontreated grapes. VviSTS7 gene expression showed a significant negative correlation with the transcript accumulation of VviPAL $(r=-0.577, p<0.01)$ and VviCHS $(r=-0.4401, p<0.05)$ (Table 2). It is well known that the application of different postharvest treatments, such as UV-B, UV-C, and high levels of $\mathrm{CO}_{2}$, which improve the quality of table grapes, also activate the expression of STS genes and the accumulation of resveratrol $[8,23,37]$. Nonetheless, this is the first study demonstrating the modulation of STS genes by ethanol treatment. Overexpression of these genes has been previously reported to improve resistance against fungal pathogens [38,39]. The fact that STS7 gene expression increases sharply in ethanoltreated samples after the shelf-life period, where the total decay is 1.83 times lower than in non-treated fruit, might be part of the molecular strategy of these grapes to cope with fungal attacks.

Table 2. Pearson correlation between VviPAL, VviCHS, VviSTS7, VviMYB13, VviMYB14, and VviMYB137 from the skin of non-treated and ethanol-treated It 681-30 table grapes stored at low temperature and after the shelf-life period.

\begin{tabular}{ccccccc}
\hline & VviPAL & VviCHS & VviSTS7 & VviMYB13 & VviMYB14 & VviMYB137 \\
\hline VviPAL & 1 & $0.451^{*}$ & $-0.577^{* *}$ & 0.030 & 0.073 & -0.338 \\
VviCHS & $0.451^{*}$ & 1 & $-0.440^{*}$ & 0.250 & -0.361 & -0.107 \\
VviSTS7 & $-0.577^{* *}$ & $-0.440^{*}$ & 1 & 0.300 & 0.056 & $0.607^{* *}$ \\
VviMYB13 & 0.030 & 0.250 & 0.300 & 1 & $0.584^{* *}$ & -0.339 \\
VviMYB14 & 0.073 & -0.361 & 0.056 & $0.584^{* *}$ & 1 & $-0.7011^{* *}$ \\
VviMYB137 & -0.338 & -0.107 & $0.607^{* *}$ & -0.339 & $-0.701^{* *}$ & 1 \\
\hline
\end{tabular}

** Correlation is significant at the 0.01 level. * Correlation is significant at the 0.05 level.

\subsubsection{Expression of VviMYB13, VviMYB14, and VviMYB137}

$M Y B$ transcription factors are known to play key roles in regulating the phenylpropanoid pathway [40]. Previous studies have reported [8,41] that the expression of MYBs can be modulated through storage at low temperature or by applying gaseous postharvest treatments. However, as of yet, their response to ethanol treatment has not been studied. The results of this study indicated that gene expression of VviMYB13 and VviMYB14 showed a sharp increase at day 18 in the skin of both treated and non-treated samples (Figure 3). It was, nevertheless, transitory in the case of VviMYB13, reaching levels similar to freshly harvested grapes at day 49 and after the shelf-life period. By contrast, the increase in VviMYB14 transcript accumulation at $0{ }^{\circ} \mathrm{C}$ also took place at day 49 in both samples, although this increase was higher in the ethanol-treated samples, decreasing after the time stored at $20^{\circ} \mathrm{C}$ to levels similar to freshly harvested grapes. The VviMYB137 transcript accumulation decreased during the storage at $0{ }^{\circ} \mathrm{C}$ in the skin of both ethanol-treated and non-treated grapes. However, the VviMYB137 gene expression rose at the end of the shelf-life period at $20^{\circ} \mathrm{C}$ in ethanol-treated samples (Figure 3).

Regarding the correlation between the expression of the three VviMYBs, the results showed that it was significantly positive between VviMYB13 and VviMYB14 $(r=0.584$, $p<0.01)$. Conversely, VviMYB137 gene expression was negatively correlated solely with VviMYB14 $(r=-0.701, p<0.01)$. According to Vannozzi et al. [42] and Tyagi et al. [43], VviMYB13, VviMYB14, and VviMYB137 could be involved in stilbene biosynthesis. However, according to the results of this study, only the VviMYB137 transcript accumulation showed a significant positive correlation with VviSTS7 gene expression $(r=0.607, p<0.01)$ in response to low temperature and ethanol-treatment in It $681-30$ grapes stored at $0{ }^{\circ} \mathrm{C}$ and during the shelf-life at $20^{\circ} \mathrm{C}$ (Table 2). 


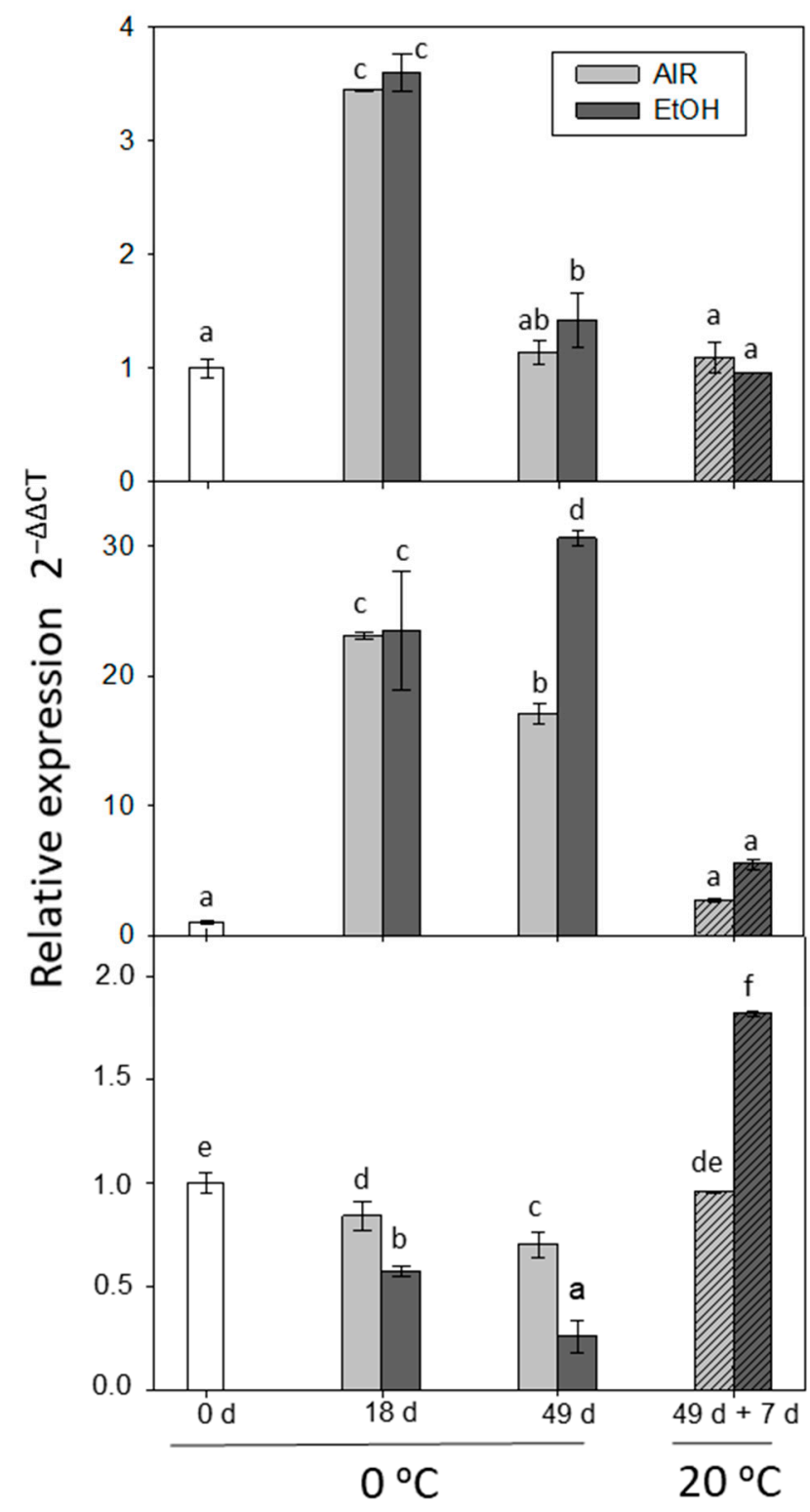

\section{VviMYB13}

VviMYB14

\section{VviMYB137}

Figure 3. Effect of low temperature and ethanol on MYB14, MYB15A, and MYB15C transcription factors gene expression in the skin of It 681-30 table grapes stored for 49 days at $0{ }^{\circ} \mathrm{C}$ and after the shelf-life period $\left(49 \mathrm{~d}+7 \mathrm{~d}\right.$ at $\left.20^{\circ} \mathrm{C}\right)$. The transcript levels of each gene were assessed by RT-qPCR and normalized using Actin 1 as a reference gene. The results were calculated relative to a calibrator sample (time 0 ) using the formula $2^{-\Delta \Delta \mathrm{Ct}}$. Values are the mean $\pm \mathrm{SD}, n=6$. Different letters on bars indicate that the means are statistically different using the Tukey-b test $(p<0.05)$.

2.3. The Effect of Storage at $0^{\circ} \mathrm{C}$ and the Shelf-Life Period at $20^{\circ} \mathrm{C}$ on the Total Phenolic and Anthocyanin Content and the Antioxidant Capacity in the Skin of Non-Treated and Ethanol-Treated It 681-30 Table Grapes

The total phenolic levels remained constant during storage in all the samples analyzed, while the total anthocyanin content increased statistically significantly in non- treated samples stored at $0{ }^{\circ} \mathrm{C}$, decreasing after 7 days at $20{ }^{\circ} \mathrm{C}$ to similar values to those achieved in freshly harvested grapes (Figure 4). Nonetheless, a significant increase was observed in ethanol-treated samples at the end of storage at $0{ }^{\circ} \mathrm{C}$. Interestingly, no increase occurred during the shelf-life at $20^{\circ} \mathrm{C}$, where a significant reduction was observed in the ethanoltreated samples in comparison with non-treated and freshly harvested grapes. Although it is already known that phenolic and anthocyanin synthesis can continue after harvest and also during low-temperature storage, it is not a common response in grapes during 
postharvest. A decrease of the total anthocyanin content and maintenance of total flavonol content was found in Napoleon table grapes stored at low temperature [44]. Furthermore, Valero et al. [45] indicated a decrease in the total anthocyanin content of Autumn Royal grapes, as well as a significant loss of total phenolics during postharvest cold storage. Similar results were observed in three-day $\mathrm{CO}_{2}$-treated and non-treated Autumn Royal grapes stored at $0{ }^{\circ} \mathrm{C}$ [22]. Concerning the ethanol treatment, the results presented in this work are in concordance with Ustun et al. [19], who reported that postharvest ethanol treatment with Antimold ${ }^{\circledR} 80$ and Antimold ${ }^{\circledR} 60$ sachets increased the anthocyanin content of Red Globe grapes at low temperature. Additionally, ethanol treatment of Cabernet Sauvignon at veraison increased anthocyanin levels during ripening [35].
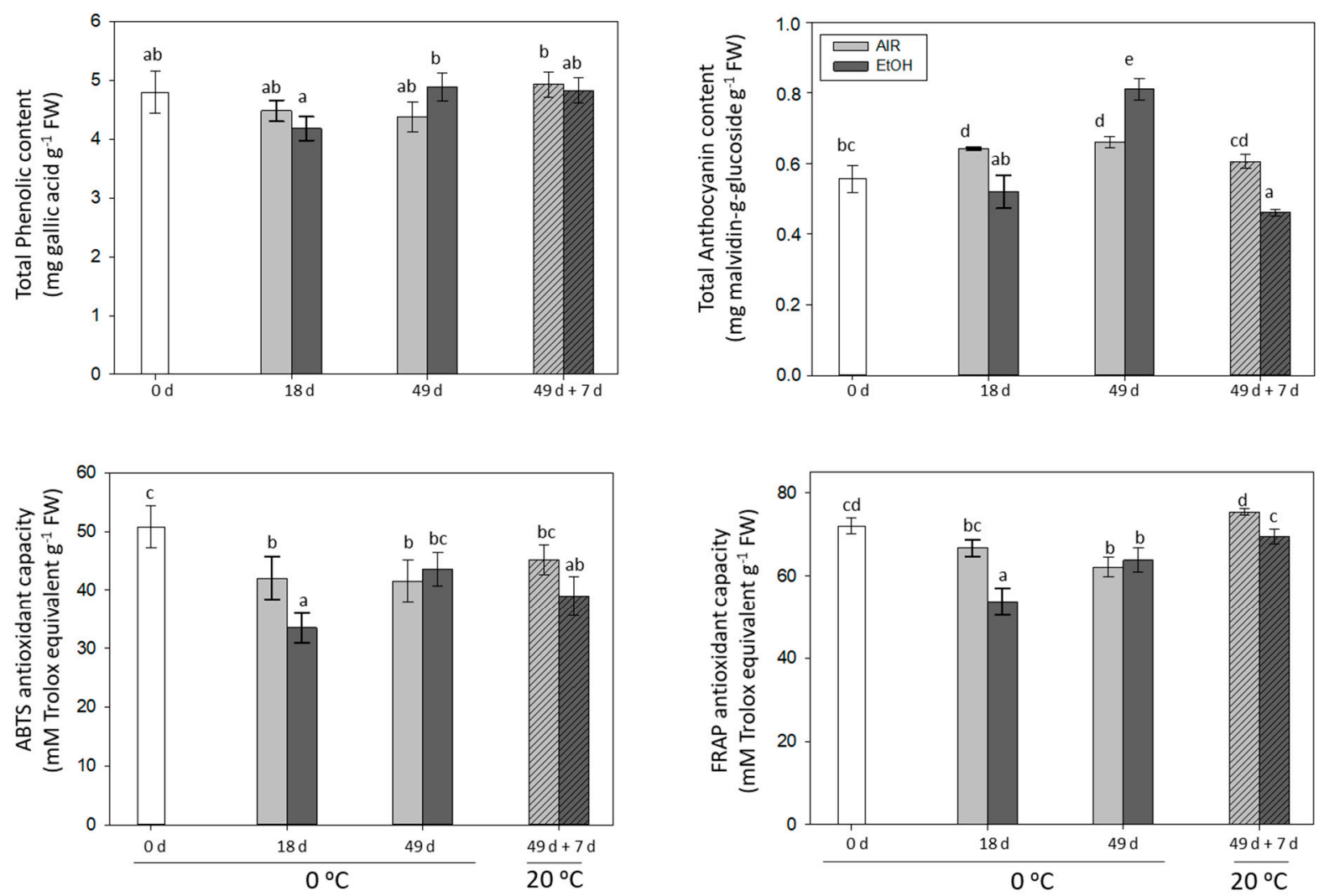

Figure 4. Changes in total phenolic content, anthocyanin content and antioxidant activity, determined by ABTS and FRAP, in the skin of non-treated and ethanol-treated It 681-30 table grapes stored up to 49 days at $0{ }^{\circ} \mathrm{C}$ and during the shelf-life period $\left(49 \mathrm{~d}+7 \mathrm{~d}\right.$ at $\left.20^{\circ} \mathrm{C}\right)$. Values are the mean $\pm \mathrm{SD}, n=3$. Different letters on the bars indicate that the values are statistically different using the Tukey-b test $(p<0.05)$.

The antioxidant capacities, which were determined by the ABTS and FRAP methods, presented similar trends (Figure 4). Indeed, both methods revealed a decrease in the antioxidant capacities of It 681-30 table grapes during storage at $0{ }^{\circ} \mathrm{C}$, showing only significant differences at day 18 , when the ethanol-treated samples showed less antioxidant capacity than non-treated samples. Nevertheless, during shelf-life at $20^{\circ} \mathrm{C}$, while the values recorded by the ABTS method were similar to those observed at the end of storage at $0{ }^{\circ} \mathrm{C}$, those achieved by the FRAP method were significantly higher. A significant positive correlation $(r=0.765, p<0.01)$ was found between the results obtained by both methods measuring the antioxidant capacity of the grapes and also between total phenolic content and antioxidant activities (FRAP: $r=0.785, p<0.01$; ABTS: $r=0.735, p<0.01$ ). By contrast, the total anthocyanin content did not correlate with either total phenolic content or antioxidant activities. In Red Globe table grapes, FRAP and TEAC values rose with the increase in anthocyanin content activated by the treatment with Antimold ${ }^{\circledR}$ sachets [19]. 
In this regard, it should be pointed out that different works studying the correlations between phenolic and anthocyanin compounds and the antioxidant capacity of grapes have shown inconsistent results. Thus, when applying one [46] of two [22] short-term $\mathrm{CO}_{2}$ treatments to table grapes, a positive correlation was obtained between their antioxidant capacity and changes in total phenolic content, but this was not the case in the pattern of total anthocyanins. Furthermore, total phenolic, flavonoids, and flavan-3-ols contents showed a positive correlation with the antioxidant capacity in different grape cultivars [47]. By contrast, when trans-resveratrol or glycine betaine was applied to maintain table grape quality during postharvest, no significant correlation was found between the antioxidant capacity changes and the total phenol and flavonoid levels [48].

2.4. The Effect of Storage at $0{ }^{\circ} \mathrm{C}$ and the Shelf-Life Period at $20^{\circ} \mathrm{C}$ on PRs Gene Expression in the Skin and Pulp of Non-Treated and Ethanol-Treated It 681-30 Table Grapes

Among the PR proteins, chitinase and $\beta$-1,3-glucanase play an essential role in plant defense mechanisms against biotic and abiotic stresses. Both enzymes are known to be able to hydrolyze polymers of fungal cell walls, and in combination, they can inhibit the growth of several pathogenic fungi in vitro [49]. This work analyzed the expression of genes that codified for class I chitinase (Vcchit1b), class I $\beta$-1,3-glucanase (Vcgns1), thaumatin (VvTL1), and osmotin (VviOsmo) in the skin and pulp of ethanol-treated and non-treated It 681-30 bunches, stored at $0{ }^{\circ} \mathrm{C}$ and after 7 days at $20^{\circ} \mathrm{C}$. The results showed that the expression of $V c c h i t 1 b$ and $V c g n s 1$ increased in the skin without significant differences between ethanol-treated and non-treated samples stored at $0{ }^{\circ} \mathrm{C}$, except for $V c c h i t 1 b$ on day 49, whose expression was higher in non-treated samples (Figure 5A). Another finding was that the accumulation of both transcripts continued increasing after 7 days at $20^{\circ} \mathrm{C}$, only showing significant differences in the case of $V c g n s 1$, whose expression was higher in the non-treated samples. By contrast, the expression of both genes did not change in the pulp of treated and non-treated grapes stored at $0^{\circ} \mathrm{C}$ (Figure 5B). Meanwhile, the shelf-life period sharply activated their expressions in ethanol-treated grapes.

The VviTL1 transcript levels only increased in the skin of ethanol-treated bunches after 18 days of storage at $0^{\circ} \mathrm{C}$ (Figure 5A). Nevertheless, VviTL1 gene expression was activated in both treated and non-treated samples during the shelf-life period and was higher in the treated grapes. Moreover, in the case of the pulp, a sharp increase in VviTL1 accumulation was recorded independently of the temperature and time of storage in ethanol-treated samples (Figure 5B). On the other hand, storage at $0{ }^{\circ} \mathrm{C}$ did not change VviOsmo gene expression in the skin of either ethanol-treated or non-treated fruit, whereas the shelf-life activated its accumulation in ethanol-treated grapes. The gene expression increased in the pulp at day 49 at $0{ }^{\circ} \mathrm{C}$ and after 7 days at $20^{\circ} \mathrm{C}$ in both samples, being significantly higher in the ethanol-treated ones after the shelf-life period (Figure 5B).

It is also interesting to note that a positive and significant correlation was found in the expression of the four $P R$ genes in the skin and the pulp (Table 3). The four $P R$ genes analyzed showed a higher expression after the shelf-life period in ethanol-treated grapes, at which point the total decay of ethanol-treated fruit was 1.83 times lower than in non-treated fruit. Other studies have shown that in loquat fruit, treatment with ethanol induced the activities of chitinase and $\beta$-1,3-glucanase, which was accompanied by a lower disease incidence of anthracnose rot in ethanol-treated loquat fruit [50]. Furthermore, in line with these results, the inhibition of anthracnose rot development in tomato appears to be related to the positive impact of ethanol vapor on host resistance [51]. Hence, it seems that the modulation of these defense-related genes could play a role in the molecular mechanisms activated by It 681-30 grapes to cope with fungal attacks during postharvest. 
A
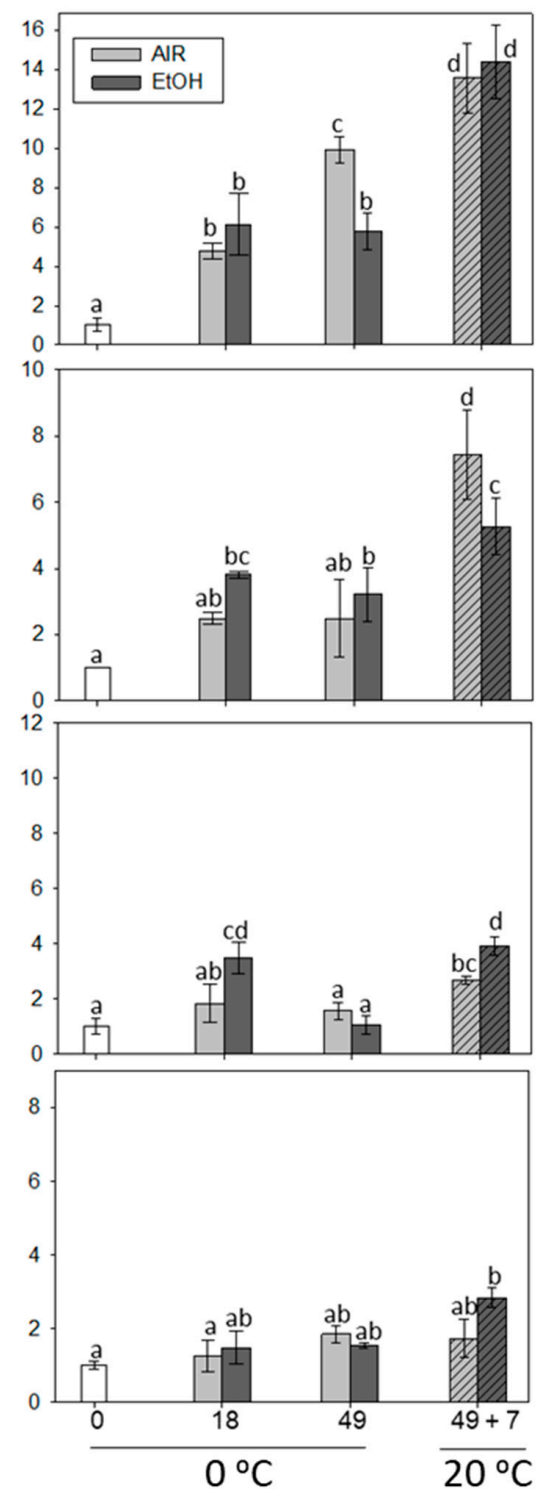

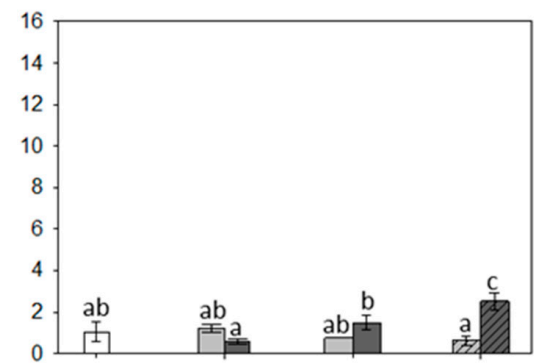

B

Vcchit1b

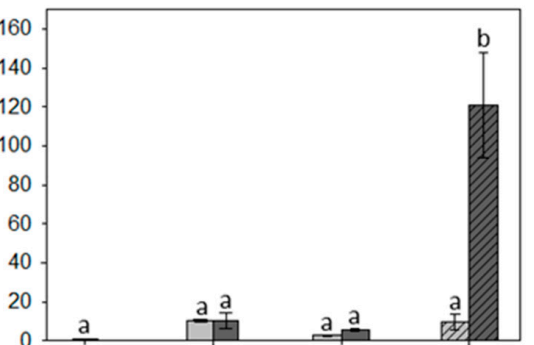

Vcgns1

VviTL1
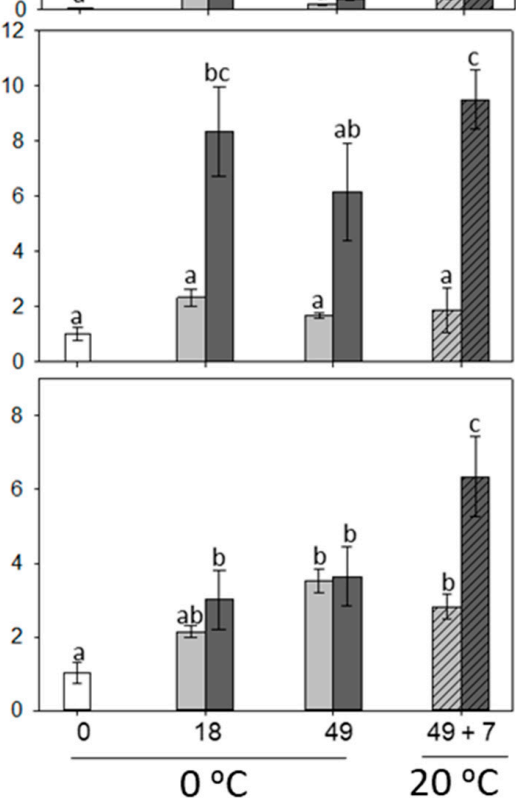

VviOsmo

Figure 5. Effect of low temperature and ethanol treatment on PRs gene expression (Vcchit1b, Vcgns1, VviTL1, and VviOsmo) in the skin (A) and pulp (B) of It 681-30 table grapes stored for 49 days at $0{ }^{\circ} \mathrm{C}$ and after the shelf-life period $(49 \mathrm{~d}+7 \mathrm{~d}$ at $20^{\circ} \mathrm{C}$ ). The transcript levels of each gene were assessed by RT-qPCR and normalized using Actin 1 as a reference gene. The results were calculated relative to a calibrator sample (time 0 ) using the formula $2^{-\Delta \Delta C t}$. Values are the mean $\pm S D, n=6$. Different letters on bars indicate that the means are statistically different using the Tukey-b test $(p<0.05)$.

Table 3. Pearson correlation between Vcgns1, Vcchit1b, VviOsmo, and VviTL1 from the skin (S) or the pulp (P) of non-treated and ethanol-treated It 681-30 table grapes stored at low temperature and after the shelf-life period.

\begin{tabular}{cccccc}
\hline & & Vcgns1 & Vcchit1b & VviOsmo & VviTL1 \\
\hline \multirow{2}{*}{ Vcgns1 } & $\mathrm{S}$ & 1 & $0.834^{* *}$ & $0.762^{* *}$ & $0.638^{* *}$ \\
& $\mathrm{P}$ & 1 & $0.827^{* *}$ & $0.834^{* *}$ & $0.790^{* *}$ \\
Vcchit1b & $\mathrm{S}$ & $0.834^{* *}$ & 1 & $0.878^{* *}$ & $0.648^{* *}$ \\
& $\mathrm{P}$ & $0.827^{* *}$ & 1 & $0.721^{* *}$ & $0.671^{* *}$ \\
VviOsmo & $\mathrm{S}$ & $0.762^{* *}$ & $0.878^{* *}$ & 1 & $0.634^{* *}$ \\
& $\mathrm{P}$ & $0.834^{* *}$ & $0.721^{* *}$ & 1 & $0.834^{* *}$ \\
VviTL1 & $\mathrm{S}$ & $0.638^{* *}$ & $0.648^{* *}$ & $0.634^{* *}$ & 1 \\
& $\mathrm{P}$ & $0.790^{* *}$ & $0.671^{* *}$ & $0.834^{* *}$ & 1 \\
\hline
\end{tabular}

** Correlation is significant at the 0.01 level. 


\subsection{The Effect of Storage at $0{ }^{\circ} \mathrm{C}$ and the Shelf-Life Period at $20^{\circ} \mathrm{C}$ on Aquaporins Gene Expression in the Skin and Pulp of Non-Treated and Ethanol-Treated It 681-30 Table Grapes}

The effect of ethanol treatment on the expression of four aquaporin genes, which are considered factors that contribute to water loss, was analyzed. Thus, four genes encoding intrinsic plasma membrane proteins (PIP1.2, PIP1.3, PIP2.1, and PIP2.2) were examined in the skin and pulp of ethanol-treated and non-treated It $681-30$ bunches stored at $0{ }^{\circ} \mathrm{C}$ and during shelf-life $(49 \mathrm{~d}+7 \mathrm{~d})$.

In the skin, PIP1.2, PIP1.3, and PIP2.2 gene expression did not change during storage at $0{ }^{\circ} \mathrm{C}$ or $20{ }^{\circ} \mathrm{C}$ (Figure 6). PIP2.1 presented a significant and transient increase in ethanoltreated grapes after 18 days of storage at $0{ }^{\circ} \mathrm{C}$, whereas PIP2.1 transcript accumulation was significantly higher in non-treated samples at the end of storage at $0{ }^{\circ} \mathrm{C}$ and after 7 days at $20^{\circ} \mathrm{C}$. The gene expression of these aquaporins correlated significantly, with the exception of PIP1.2 with PIP2.2 (Table 4). The PIP2.2 transcript levels in the pulp did not change over the storage period, while the PIP1.2 and PIP1.3 levels significantly increased both after 18 days and during shelf-life in non-treated samples. PIP2.1, for its part, showed a delay in the increase that was significant at the end of storage and was maintained during shelf-life. This study could only establish a significant correlation between PIP1.2 and PIP1.3 gene expression $(r=0.81, p<0.01)$ (Table 4$)$.
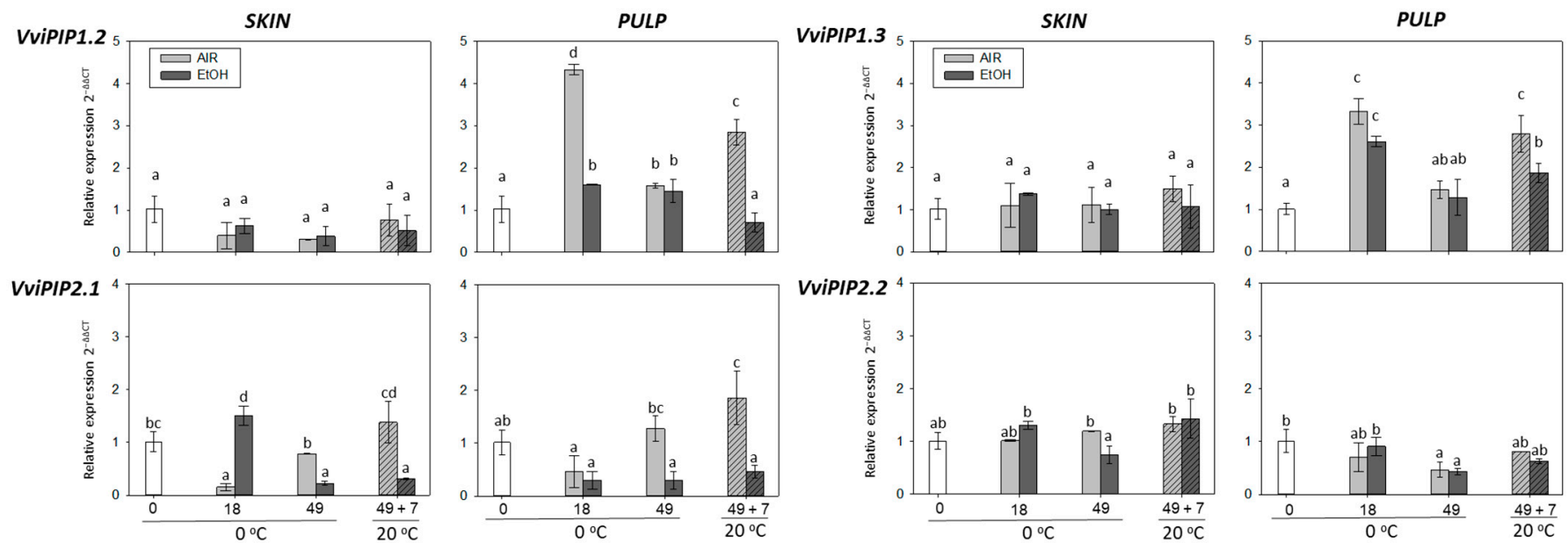

Figure 6. Effect of low temperature and ethanol treatment on aquaporins gene expression (PIP1.2, PIP1.3, PIP2.1, and PIP2.2) in the skin and pulp of It 681-30 table grapes stored for 49 days at $0{ }^{\circ} \mathrm{C}$ and after the shelf-life period $\left(49 \mathrm{~d}+7 \mathrm{~d}\right.$ at $\left.20^{\circ} \mathrm{C}\right)$. The transcript levels of each gene were assessed by RT-qPCR and normalized using Actin1 as a reference gene. The results were calculated relative to a calibrator sample (time 0 ) using the formula $2^{-\Delta \Delta \mathrm{Ct}}$. Values are the mean $\pm \mathrm{SD}, n=6$. Different letters on bars indicate that the means are statistically different using the Tukey-b test $(p<0.05)$.

Table 4. Pearson correlation between aquaporins from the skin (S) or the pulp (P) of non-treated and ethanol-treated It 681-30 table grapes stored at low temperature and after the shelf-life period.

\begin{tabular}{cccccc}
\hline & & VviPIP12 & VviPIP13 & VviPIP21 & VviPIP22 \\
\hline \multirow{2}{*}{ VviPIP12 } & $\mathrm{S}$ & 1 & $0.579^{* *}$ & $0.554^{* *}$ & 0.406 \\
& $\mathrm{P}$ & 1 & $0.810^{* *}$ & 0.170 & 0.053 \\
VviPIP13 & $\mathrm{S}$ & $0.579^{* *}$ & 1 & $0.497^{*}$ & $0.580^{* *}$ \\
& $\mathrm{P}$ & $0.810^{* *}$ & 1 & 0.109 & 0.255 \\
VviPIP21 & $\mathrm{S}$ & $0.554^{* *}$ & $0.497^{*}$ & 1 & $0.451^{*}$ \\
& $\mathrm{P}$ & 0.170 & $0.109^{*}$ & 1 & 0.264 \\
VviPIP22 & $\mathrm{S}$ & 0.406 & $0.580^{* *}$ & $0.451^{*}$ & 1 \\
& $\mathrm{P}$ & 0.053 & 0.255 & 0.264 & 1 \\
\hline
\end{tabular}

** Correlation is significant at the 0.01 level. * Correlation is significant at the 0.05 level.

Some authors have suggested that aquaporins, especially PIPS, contribute, to a lesser extent, to water transport when the fruit cuticle presents microcracks [52]. In tomato, an 
enhanced expression of PIP aquaporin genes linked to increased water loss was reported in melatonin-treated grapes stored at $15^{\circ} \mathrm{C}$ [53]. In strawberry, PIP1 and PIP2 gene expression increased coincident with a decrease in firmness during ripening, indicating that the reduction of fruit turgor together with the induction of aquaporins may accelerate the water outflow from cells [54]. Miranda et al. [55] provided evidence for a significant reduction in water loss linked to the down-regulation of two PIP genes in two cultivars of sweet cherries treated with melatonin. In this sense, the results showed that the highest increment in PIPs gene expression in It 681-30 grapes took place in non-treated fruit that exhibited the highest water loss. Similar results were found in Cardinal tables grapes, where an increase in PIPs gene expression was found in grapes stored at $0{ }^{\circ} \mathrm{C}$ [41].

\section{Material and Methods}

\subsection{Plant Material and Storage Conditions}

It 681-30 table grapes (Vitis vinifera L.) were collected in Abarán, Murcia, Spain (latitude: $38^{\circ} 12^{\prime} 00^{\prime \prime} \mathrm{N}$; longitude: $01^{\circ} 24^{\prime} 00^{\prime \prime} \mathrm{W}$; altitude $173 \mathrm{~m}$ ) at optimum maturity $(19.2 \%$ total soluble solids, $0.37 \%$ tartaric acid) in November 2018. Bunches were transferred to the ICTAN in Madrid (Spain) the same day of collection and those that did not present mechanical or pathological defects were randomly divided into two lots, each consisting of nine perforated polyethylene bags with four bunches per bag (about $3 \mathrm{~kg}$ ). One batch was stored under normal atmospheric conditions (non-treated) for 49 days at $0 \pm 0.5^{\circ} \mathrm{C}$ with a relative humidity of $95 \%$. The other batch was stored in the presence of two 6-g ethanol pads per bag (Antimold ${ }^{\circledR} 60$, Freund Industrial Co., Ltd., Tokyo, Japan) and stored at the same conditions of non-treated fruit. The ethanol pad allowed the ethanol vapor to diffuse gradually. The Antimold ${ }^{\circledR}$ sachets are heat-sealed and are made of a laminated layer of paper and ethyl vinyl acetate copolymer, and contain microencapsulated food grade ethanol ( $58 \%$ by weight) absorbed onto silicon dioxide powder $(35 \%)$. The encapsulated ethanol is released when in contact with water vapor. After the storage at $0{ }^{\circ} \mathrm{C}$, both ethanol-treated and non-treated fruit were removed from the perforated polyethylene bags and transferred to boxes at $20^{\circ} \mathrm{C}$ and stored for 7 days to simulate commercial shelf-life conditions. Eight bunches (approximately $750 \mathrm{~g}$ each bunch) were sampled at different time points and the skin and pulp were frozen in liquid nitrogen and stored at $-80{ }^{\circ} \mathrm{C}$ until further analysis.

\subsection{Quality Assessments}

Soluble solids content (SSC), titratable acidity (TA), and $\mathrm{pH}$ were determined in ethanol-treated and non-treated samples at day 0 and at day 49 of storage at $0{ }^{\circ} \mathrm{C}$ and after the shelf-life of 7 days at $20^{\circ} \mathrm{C}$, as described by Sanchez-Ballesta et al. [3]. Bunch weight was recorded on the day of harvest and after 49 days at $0{ }^{\circ} \mathrm{C}$ and 7 days at $20^{\circ} \mathrm{C}$. Cumulative weight losses were expressed as a percentage loss of the original weight. Total decay was expressed as the percentage of decayed berries at day 49 and after 7 days at $20^{\circ} \mathrm{C}$ with respect to the original bunch weight. Rachis browning was determined by using the subjective scale as described by Vazquez-Hernandez et al. [56].

\subsection{Relative Gene Expression by Quantitative Real-Time RT-PCR (RT-qPCR)}

Total RNA extraction and cDNA synthesis were performed according to Romero et al. [57]. Relative expression of PRs (Vcchit1b, Vcgns1, VviTL, and VviOsmo1), phenylpropanoid (VviPAL, VviCHS, and VviSTS7), transcription factor (VviMYB13, VviMYB14, and VviMYB137), and aquaporin (VviPIP1.2, VviPIP1.3, VviPIP2.1, and VviPIP2.2) genes were studied in the skin and pulp of non-treated and ethanol-treated grapes stored at $0{ }^{\circ} \mathrm{C}$ for up to 49 days and after 7 days at $20^{\circ} \mathrm{C}$ by RT-qPCR as described by Rosales et at [58]. Gene-specific primers were designed using Primer 3 software [59] and used to amplify specific products (Supplementary Table S1). Actin 1 (XM 002282480) from V. vinifera was used as the internal control ( $F w \_A c t 1:$ CTTGCATCCCTCAGCACCTT, Rv_Act1: TCCTGTGGACAATGGATGGA). The specificity of products was validated according to Romero 
et al. [57]. Three biological replicates and two technical replicates were performed for each sample.

\subsection{Analysis of Total Anthocyanin Content}

The determination of the total anthocyanin content in the skin of It 681-30 table grapes was carried out as described by Sanchez-Ballesta et al. [60]. For the extraction of total anthocyanins, $0.25 \mathrm{~g}$ of skin tissue from non-treated and ethanol-treated table grapes were homogenized with $0.75 \mathrm{~mL}$ of methanol $(1 \% \mathrm{HCl}$ acidified) using ultra sonication in cold water for $10 \mathrm{~min}$. The extracts were centrifuged in cold at 10,000 $\mathrm{g}$ for $10 \mathrm{~min}$ and supernatants were collected. The previous steps were repeated until a volume of $1.5 \mathrm{~mL}$ was obtained. Samples were filtered with $0.45 \mu \mathrm{m}$ nylon filters and stored at $-80{ }^{\circ} \mathrm{C}$. During the extraction, tubes were kept in the dark to avoid oxidation of the compounds. The results were expressed as mg of malvidin-3-glucoside $\mathrm{g}^{-1}$ of fresh weight (FW).

\subsection{Analysis of Total Phenolic Content by Folin-Ciocalteu Method}

For the extraction of phenolic compounds, $0.25 \mathrm{~g}$ of skin tissue from non-treated and ethanol-treated table grapes stored at $0{ }^{\circ} \mathrm{C}$ and after 7 days at $20{ }^{\circ} \mathrm{C}$ were homogenized with $0.5 \mathrm{~mL}$ of a solution of methanol $(1 \% \mathrm{HCl}$ acidified)-water $(v / v)$ and mixed for $60 \mathrm{~min}$ at room temperature (RT). The extracts were centrifuged at $10,000 \times g$ for $10 \mathrm{~min}$ and the supernatants were collected. The pellet was then homogenized with acetonitrile $70 \%$, incubated for $60 \mathrm{~min}$ at RT, and centrifuged at $10,000 \times g$ at RT for $10 \mathrm{~min}$. Supernatant was collected and combined with previous extract supernatants. The final volume was set to $1 \mathrm{~mL}$ with methanol 50\%-acetonitrile $70 \%$. The supernatants were stored at $-20^{\circ} \mathrm{C}$. The content of total phenolic compounds in the extracts was determined by the Folin-Ciocalteu method [61] and expressed as mg of gallic acid equivalents $\mathrm{g}^{-1} \mathrm{FW}$.

3.6. Antioxidant Activities Measured by 2,2-Azino-Bis-3-Ethylbenzothiazoline-6-Sulfonic Acid (ABTS) and Ferric Reducing Antioxidant Power (FRAP) Methods

For the determination of the antioxidant activity of It 681-30 table grapes, the same extracts as for the determination of total phenolic content were used. ABTS and FRAP methods were performed according to Romero et al. [46].

\subsection{Statistical Analysis}

The software SPSS v23.0 (IBM) was used for the statistical analysis. The different data obtained were analyzed by ANOVA (one-way analysis of variance), and their means \pm standard deviation were grouped in subsets by the Tukey-b test $(p<0.05)$. The relationship between expression data was described as the Pearson product-moment correlation coefficient $(r), p<0.01$ or $p<0.05$.

\section{Conclusions}

The application of ethanol vapor treatments to It 681-30 table grapes reduced the deterioration of table grape quality during storage at $0^{\circ} \mathrm{C}$ and after the 7 -day shelf-life period at $20^{\circ} \mathrm{C}$. However, the total phenolic content and the antioxidant capacity seems not to play a role in the improvement of table grape quality by the ethanol treatment. By contrast, among the mechanisms triggered in It 681-30 table grapes to cope with lowtemperature storage and shelf-life at $20^{\circ} \mathrm{C}$, the activation of STS7 and PRs together with PIP gene expression could play an important role in controlling fungal attack and weight loss, respectively. The results from this work open an interesting research line in order to extend the postharvest storage in table grapes but further works would be necessary to unravel the mechanisms implicated in the effect of ethanol treatment.

Supplementary Materials: The following are available online at https:/ /www.mdpi.com/article/10 .3390/ijms22158138/s1. 
Author Contributions: Conceptualization, M.T.S.-B. and I.R.; methodology, M.T.S.-B. and I.R., formal analysis, M.V.-H. and I.R.; investigation, M.T.S.-B. and I.R.; resources, M.T.; data curation, M.V.H., M.T.S.-B. and I.R.; writing-original draft preparation, M.T.S.-B. and I.R.; writing-review and editing, M.T.S.-B. and I.R.; supervision, M.T.S.-B. and M.I.E.; project administration, M.T.S.-B. and C.M.; funding acquisition, M.T.S.-B., M.I.E. and C.M. All authors have read and agreed to the published version of the manuscript.

Funding: This work was supported by CICYT projects AGL2014-53081-R and AGL2017-85291-R (MINECO/AEI/FEDER, UE).

Institutional Review Board Statement: Not applicable.

Informed Consent Statement: Not applicable.

Data Availability Statement: Not applicable.

Conflicts of Interest: The authors declare no conflict of interest.

\section{References}

1. Romero, I.; Vazquez-Hernandez, M.; Maestro-Gaitan, I.; Escribano, M.I.; Merodio, C.; Sanchez-Ballesta, M.T. Table Grapes during Postharvest Storage: A Review of the Mechanisms Implicated in the Beneficial Effects of Treatments Applied for Quality Retention. Int. J. Mol. Sci. 2020, 21, 9320. [CrossRef] [PubMed]

2. Artés-Hernández, F.; Aguayo, E.; Artés, F. Alternative atmosphere treatments for keeping quality of 'Autumn seedless' table grapes during long-term cold storage. Postharvest Biol. Technol. 2004, 31, 59-67. [CrossRef]

3. Sanchez-Ballesta, M.T.; Jiménez, J.B.; Romero, I.; Orea, J.M.; Maldonado, R.; Ureña, G.; Escribano, M.I.; Merodio, C. Effect of high $\mathrm{CO}_{2}$ pretreatment on quality, fungal decay and molecular regulation of stilbene phytoalexin biosynthesis in stored table grapes. Postharvest Biol. Technol. 2006, 42, 209-216. [CrossRef]

4. Chen, X.; Zhu, Z.; Zhang, X.; Antoce, A.O.; Mu, W. Modeling the Microbiological Shelf Life of Table Grapes and Evaluating the Effects of Constant Concentrations of Sulfur Dioxide. J. Food Process. Preserv. 2016, 41, e13058. [CrossRef]

5. Wu, Z.; Yuan, X.; Li, H.; Liu, F.; Wang, Y.; Li, J.; Cai, H.; Wang, Y. Heat acclimation reduces postharvest loss of table grapes during cold storage-Analysis of possible mechanisms involved through a proteomic approach. Postharvest Biol. Technol. 2015, 105, 26-33. [CrossRef]

6. Lu, S.L.; Yang, X.Z.; Li, X.H.; Shen, L.M.; Ma, H.Y. Effect of Sulfur Dioxide Treatment on Storage Quality and SO $\mathrm{S}_{2}$ Residue of Victoria Grape. Adv. Mater. Res. 2013, 798-799, 1033-1036. [CrossRef]

7. Ni, Z.-J.; Hu, K.-D.; Song, C.-B.; Ma, R.-H.; Li, Z.-R.; Zheng, J.-L.; Fu, L.-H.; Wei, Z.-J.; Zhang, H. Hydrogen Sulfide Alleviates Postharvest Senescence of Grape by Modulating the Antioxidant Defenses. Oxidative Med. Cell. Longev. 2016, 2016, 1-14. [CrossRef] [PubMed]

8. Maoz, I.; De Rosso, M.; Kaplunov, T.; Vedova, A.D.; Sela, N.; Flamini, R.; Lewinsohn, E.; Lichter, A. Metabolomic and transcriptomic changes underlying cold and anaerobic stresses after storage of table grapes. Sci. Rep. 2019, 9, 1-14. [CrossRef]

9. Dao, T.; Dantigny, P. Control of food spoilage fungi by ethanol. Food Control. 2011, 22, 360-368. [CrossRef]

10. Pesis, E. The role of the anaerobic metabolites, acetaldehyde and ethanol, in fruit ripening, enhancement of fruit quality and fruit deterioration. Postharvest Biol. Technol. 2005, 37, 1-19. [CrossRef]

11. Mori, T.; Terai, H.; Yamauchi, N.; Suzuki, Y. Effects of postharvest ethanol vapor treatment on the ascorbate-glutathione cycle in broccoli florets. Postharvest Biol. Technol. 2009, 52, 134-136. [CrossRef]

12. Gutiérrez-Martínez, P.; Osuna-López, S.; Calderón-Santoyo, M.; Cruz-Hernández, A.; Bautista-Baños, S. Influence of ethanol and heat on disease control and quality in stored mango fruits. LWT 2012, 45, 20-27. [CrossRef]

13. Ponzo, F.S.; Benato, E.A.; Da Silva, B.M.P.; Cia, P. Ethanol on the postharvest control of anthracnose in 'Kumagai' guava. Bragantia 2017, 77, 160-167. [CrossRef]

14. Ji, Y.; Hu, W.; Jiang, A.; Xiu, Z.; Liao, J.; Yang, X.; Guan, Y.; Saren, G.; Feng, K. Effect of ethanol treatment on the quality and volatiles production of blueberries after harvest. J. Sci. Food Agric. 2019, 99, 6296-6306. [CrossRef]

15. Karabulut, O.A.; Gabler, F.M.; Mansour, M.; Smilanick, J.L. Postharvest ethanol and hot water treatments of table grapes to control gray mold. Postharvest Biol. Technol. 2004, 34, 169-177. [CrossRef]

16. Chervin, C.; Westercamp, P.; Monteils, G. Ethanol vapours limit Botrytis development over the postharvest life of table grapes. Postharvest Biol. Technol. 2005, 36, 319-322. [CrossRef]

17. Lurie, S.; Pesis, E.; Gadiyeva, O.; Feygenberg, O.; Ben-Arie, R.; Kaplunov, T.; Zutahy, Y.; Lichter, A. Modified ethanol atmosphere to control decay of table grapes during storage. Postharvest Biol. Technol. 2006, 42, 222-227. [CrossRef]

18. Candir, E.; Ozdemir, A.E.; Kamiloglu, O.; Soylu, E.M.; Dilbaz, R.; Ustun, D. Modified atmosphere packaging and ethanol vapor to control decay of 'Red Globe' table grapes during storage. Postharvest Biol. Technol. 2012, 63, 98-106. [CrossRef]

19. Ustun, D.; Candir, E.; Ozdemir, A.E.; Kamiloglu, O.; Soylu, E.M.; Dilbaz, R. Effects of modified atmosphere packaging and ethanol vapor treatment on the chemical composition of 'Red Globe' table grapes during storage. Postharvest Biol. Technol. 2012, 68, 8-15. [CrossRef] 
20. Sharma, A.; Shahzad, B.; Rehman, A.; Bhardwaj, R.; Landi, M.; Zheng, B. Response of Phenylpropanoid Pathway and the Role of Polyphenols in Plants under Abiotic Stress. Molecules 2019, 24, 2452. [CrossRef] [PubMed]

21. Yadav, V.; Wang, Z.; Wei, C.; Amo, A.; Ahmed, B.; Yang, X.; Zhang, X. Phenylpropanoid Pathway Engineering: An Emerging Approach towards Plant Defense. Pathogens 2020, 9, 312. [CrossRef]

22. Romero, I.; Domínguez, I.; Morales-Diaz, N.; Escribano, M.I.; Merodio, C.; Sanchez-Ballesta, M.T. Regulation of flavonoid biosynthesis pathway by a single or dual short-term $\mathrm{CO}_{2}$ treatment in black table grapes stored at low temperature. Plant Physiol. Biochem. 2020, 156, 30-38. [CrossRef]

23. Sanchez-Ballesta, M.T.; Alvarez, I.; Escribano, M.I.; Merodio, C.; Romero, I. Effect of high $\mathrm{CO}_{2}$ levels and low temperature on stilbene biosynthesis pathway gene expression and stilbenes production in white, red and black table grape cultivars during postharvest storage. Plant Physiol. Biochem. 2020, 151, 334-341. [CrossRef]

24. Duarte-Sierra, A.; Aispuro-Hernandez, E.; Vargas-Arispuro, I.; Islas-Osuna, M.A.; González-Aguilar, G.A.; Martinez-Tellez, M.A. Quality and PR gene expression of table grapes treated with ozone and sulfur dioxide to control fungal decay. J. Sci. Food Agric. 2015, 96, 2018-2024. [CrossRef] [PubMed]

25. Romero, I.; Fernandez-Caballero, C.; Goñi, O.; Escribano, M.I.; Merodio, C.; Sanchez-Ballesta, M.T. Functionality of a class I beta-1,3-glucanase from skin of table grapes berries. Plant Sci. 2008, 174, 641-648. [CrossRef]

26. Fernandez-Caballero, C.; Romero, I.; Goñi, O.; Escribano, M.I.; Merodio, C.; Sanchez-Ballesta, M.T. Characterization of an Antifungal and Cryoprotective Class I Chitinase from Table Grape Berries (Vitis vinifera Cv. Cardinal). J. Agric. Food Chem. 2009, 57, 8893-8900. [CrossRef] [PubMed]

27. Dhekney, S.A.; Li, Z.T.; Gray, D.J. Grapevines engineered to express cisgenic Vitis vinifera thaumatin-like protein exhibit fungal disease resistance. Vitr. Cell. Dev. Biol. 2011, 47, 458-466. [CrossRef]

28. Nookaraju, A.; Agrawal, D.C. Enhanced tolerance of transgenic grapevines expressing chitinase and $\beta$-1,3-glucanase genes to downy mildew. Plant Cell Tissue Organ Cult. (PCTOC) 2012, 111, 15-28. [CrossRef]

29. Maurel, C.; Verdoucq, L.; Luu, D.-T.; Santoni, V. Plant Aquaporins: Membrane Channels with Multiple Integrated Functions. Annu. Rev. Plant Biol. 2008, 59, 595-624. [CrossRef]

30. Grimplet, J.; Deluc, L.G.; Tillett, R.L.; Wheatley, M.D.; Schlauch, K.A.; Cramer, G.R.; Cushman, J.C. Tissue-specific mRNA expression profiling in grape berry tissues. BMC Genom. 2007, 8, 187. [CrossRef]

31. Jang, J.Y.; Kim, D.G.; Kim, Y.O.; Kim, J.S.; Kang, H. An Expression Analysis of a Gene Family Encoding Plasma Membrane Aquaporins in Response to Abiotic Stresses in Arabidopsis thaliana. Plant Mol. Biol. 2004, 54, 713-725. [CrossRef]

32. Xu, Y.; Hu, W.; Liu, J.; Zhang, J.; Jia, C.; Miao, H.; Xu, B.; Jin, Z. A banana aquaporin gene, MaPIP1;1, is involved in tolerance to drought and salt stresses. BMC Plant Biol. 2014, 14, 59. [CrossRef] [PubMed]

33. Candir, E.; Kamiloglu, O.; Erhan Ozdemir, A.; Celebi, S.; Coskun, H.; Ars, M.; Alkan, S. Alternative postharvest treatments to control decay of table grapes during storage. J. Appl. Bot. Food Qual. 2011, 84, 72-75.

34. Cantos-Villar, E.; Espín, J.C.; Tomás-Barberán, F.A. Postharvest Induction Modeling Method Using UV Irradiation Pulses for Obtaining Resveratrol-Enriched Table Grapes: A New "Functional" Fruit? J. Agric. Food Chem. 2001, 49, 5052-5058. [CrossRef]

35. El Kereamy, A.; Chervin, C.; Souquet, J.-M.; Moutounet, M.; Monje, M.-C.; Nepveu, F.; Mondies, H.; Ford, C.M.; Van Heeswijck, R.; Roustan, J.-P. Ethanol triggers grape gene expression leading to anthocyanin accumulation during berry ripening. Plant Sci. 2002, 163, 449-454. [CrossRef]

36. Yan, S.; Yang, T.; Luo, Y. The mechanism of ethanol treatment on inhibiting lettuce enzymatic browning and microbial growth. LWT 2015, 63, 383-390. [CrossRef]

37. Sheng, K.; Zheng, H.; Shui, S.; Yan, L.; Liu, C.; Zheng, L. Comparison of postharvest UV-B and UV-C treatments on table grape: Changes in phenolic compounds and their transcription of biosynthetic genes during storage. Postharvest Biol. Technol. 2018, 138, 74-81. [CrossRef]

38. Zhu, Y.J.; Agbayani, R.; Jackson, M.C.; Tang, C.S.; Moore, P.H. Expression of the grapevine stilbene synthase gene VST1 in papaya provides increased resistance against diseases caused by Phytophthora palmivora. Planta 2004, 220, 241-250. [CrossRef] [PubMed]

39. Kiselev, K.V.; Aleynova, O.A. Influence of overexpression of stilbene synthase VaSTS7 gene on resveratrol production in transgenic cell cultures of grape Vitis amurensis Rupr. Appl. Biochem. Microbiol. 2016, 52, 56-60. [CrossRef]

40. Cao, Y.; Li, K.; Li, Y.; Zhao, X.; Wang, L. MYB Transcription Factors as Regulators of Secondary Metabolism in Plants. Biology 2020, 9, 61. [CrossRef]

41. Rosales, R.; Romero, I.; Fernandez-Caballero, C.; Escribano, M.I.; Merodio, C.; Sanchez-Ballesta, M.T. Low Temperature and Short-Term High- $\mathrm{CO}_{2}$ Treatment in Postharvest Storage of Table Grapes at Two Maturity Stages: Effects on Transcriptome Profiling. Front. Plant Sci. 2016, 7, 1020. [CrossRef]

42. Vannozzi, A.; Wong, D.C.J.; Höll, J.; Hmmam, I.; Matus, J.T.; Bogs, J.; Ziegler, T.; Dry, I.; Barcaccia, G.; Lucchin, M. Combinatorial Regulation of Stilbene Synthase Genes by WRKY and MYB Transcription Factors in Grapevine (Vitis vinifera L.). Plant Cell Physiol. 2018, 59, 1043-1059. [CrossRef]

43. Tyagi, K.; Maoz, I.; Kochanek, B.; Sela, N.; Lerno, L.; Ebeler, S.E.; Lichter, A. Cytokinin but not gibberellin application had major impact on the phenylpropanoid pathway in grape. Hortic. Res. 2021, 8, 1-15. [CrossRef]

44. Artés-Hernández, F.; Artés, F.; Tomas-Barberan, F. Quality and Enhancement of Bioactive Phenolics in Cv. Napoleon Table Grapes Exposed to Different Postharvest Gaseous Treatments. J. Agric. Food Chem. 2003, 51, 5290-5295. [CrossRef] [PubMed] 
45. Valero, D.; Valverde, J.; Martínez-Romero, D.; Guillen, F.; Castillo, S.; Serrano, M. The combination of modified atmosphere packaging with eugenol or thymol to maintain quality, safety and functional properties of table grapes. Postharvest Biol. Technol. 2006, 41, 317-327. [CrossRef]

46. Romero, I.; Domínguez, I.; Doménech-Carbó, A.; Gavara, R.; Escribano, M.I.; Merodio, C.; Sanchez-Ballesta, M.T. Effect of high levels of $\mathrm{CO}_{2}$ on the electrochemical behavior and the enzymatic and non-enzymatic antioxidant systems in black and white table grapes stored at $0{ }^{\circ} \mathrm{C}$. J. Sci. Food Agric. 2019, 99, 6859-6867. [CrossRef] [PubMed]

47. Xu, C.; Zhang, Y.; Cao, L.; Lu, J. Phenolic compounds and antioxidant properties of different grape cultivars grown in China. Food Chem. 2010, 119, 1557-1565. [CrossRef]

48. Awad, M.A.; Al-Qurashi, A.D.; Mohamed, S.A. Postharvest trans -resveratrol and glycine betaine treatments affect quality, antioxidant capacity, antioxidant compounds and enzymes activities of 'El-Bayadi' table grapes after storage and shelf life. Sci. Hortic. 2015, 197, 350-356. [CrossRef]

49. Van Loon, L.C.; Rep, M.; Pieterse, C.M.J. Significance of Inducible Defense-related Proteins in Infected Plants. Annu. Rev. Phytopathol. 2006, 44, 135-162. [CrossRef]

50. Wang, K.; Cao, S.; Di, Y.; Liao, Y.; Zheng, Y. Effect of ethanol treatment on disease resistance against anthracnose rot in postharvest loquat fruit. Sci. Hortic. 2015, 188, 115-121. [CrossRef]

51. Tzortzakis, N.G. Ethanol, vinegar and Origanum vulgare oil vapour suppress the development of anthracnose rot in tomato fruit. Int. J. Food Microbiol. 2010, 142, 14-18. [CrossRef]

52. Chen, Y.-H.; Khanal, B.P.; Linde, M.; Debener, T.; Alkio, M.; Knoche, M. Expression of putative aquaporin genes in sweet cherry is higher in flesh than skin and most are downregulated during development. Sci. Hortic. 2019, 244, 304-314. [CrossRef]

53. Sun, Q.; Zhang, N.; Wang, J.; Zhang, H.; Li, D.; Shi, J.; Li, R.; Weeda, S.; Zhao, B.; Ren, S.; et al. Melatonin promotes ripening and improves quality of tomato fruit during postharvest life. J. Exp. Bot. 2014, 66, 657-668. [CrossRef]

54. Alleva, K.; Marquez, M.; Villarreal, N.; Mut, P.; Bustamante, C.; Bellati, J.; Martínez, G.; Civello, M.; Amodeo, G. Cloning, functional characterization, and co-expression studies of a novel aquaporin (FaPIP2;1) of strawberry fruit. J. Exp. Bot. 2010, 61, 3935-3945. [CrossRef] [PubMed]

55. Miranda, S.; Vilches, P.; Suazo, M.; Pavez, L.; García, K.; Méndez, M.A.; González, M.; Meisel, L.A.; Defilippi, B.G.; del Pozo, T. Melatonin triggers metabolic and gene expression changes leading to improved quality traits of two sweet cherry cultivars during cold storage. Food Chem. 2020, 319, 126360. [CrossRef] [PubMed]

56. Vázquez-Hernández, M.; Romero, I.; Escribano, M.I.; Merodio, C.; Sanchez-Ballesta, M.T. Deciphering the Role of CBF/DREB Transcription Factors and Dehydrins in Maintaining the Quality of Table Grapes cv. Autumn Royal Treated with High $\mathrm{CO}_{2}$ Levels and Stored at $0^{\circ} \mathrm{C}$. Front. Plant Sci. 2017, 8, 1591. [CrossRef] [PubMed]

57. Romero, I.; Vázquez-Hernández, M.; Escribano, M.I.; Merodio, C.; Sanchez-Ballesta, M.T. Expression Profiles and DNA-Binding Affinity of Five ERF Genes in Bunches of Vitis vinifera cv. Cardinal Treated with High Levels of $\mathrm{CO}_{2}$ at Low Temperature. Front. Plant Sci. 2016, 7, 1748. [CrossRef]

58. Rosales, R.; Fernandez-Caballero, C.; Romero, I.; Escribano, M.I.; Merodio, C.; Sanchez-Ballesta, M.T. Molecular analysis of the improvement in rachis quality by high $\mathrm{CO}_{2}$ levels in table grapes stored at low temperature. Postharvest Biol. Technol. 2013, 77, 50-58. [CrossRef]

59. Untergasser, A.; Cutcutache, I.; Koressaar, T.; Ye, J.; Faircloth, B.; Remm, M.; Rozen, S.G. Primer3-New capabilities and interfaces. Nucleic Acids Res. 2012, 40, e115. [CrossRef]

60. Sanchez-Ballesta, M.T.; Romero, I.M.; Jiménez, J.B.; Orea, J.M.; Ureña, A.G.; Escribano, M.I.; Merodio, C. Involvement of the phenylpropanoid pathway in the response of table grapes to low temperature and high $\mathrm{CO}_{2}$ levels. Postharvest Biol. Technol. 2007, 46, 29-35. [CrossRef]

61. Singleton, V.; Rossi, J. Colorimetry of total phenolics with phosphomolybdic-phosphotungstic acid reagents. Am. J. Enol. Vitic. $1965,16,144-158$. 